\section{CITAÇÃO}

Burczyk, K., Rodrigues, J.F. (2018)

Origami e Vírus,

Rev. Ciência Elem., V6(02):049.

doi.org/10.24927/rce2018.049

\section{EDITOR}

José Ferreira Gomes,

Universidade do Porto

\section{EDITOR CONVIDADO}

José Francisco Rodrigues,

Universidade de Lisboa

\section{RECEBIDO EM}

19 de abril de 2018

\section{ACEITE EM}

22 de maio de 2018

\section{PUBLICADO EM}

18 de junho de 2018

\section{COPYRIGHT}

(C) Casa das Ciências 2018.

Este artigo é de acesso livre, distribuído sob licença Creative Commons com a designação CC-BY-NC-SA 4.0, que permite a utilização e a partilha para fins não comerciais, desde que citado o autor e a fonte original do artigo.

\title{
Origami e Vírus
}

in imagem.casadasciencias.org

Eu crio as minhas obras de arte de pequenos pedaços de papel com espirais que conectam e ligam os elementos a uma grande estrutura. Na obra de origami acabada, a que chamo Voltinhas, estas espirais vivem e trabalham. Forças de tensão e fricção contrapõem-se à gravidade e mantêm a forma estável. Nas minhas criações procuro estar perto da natureza. Quando criamos ou estudamos modelos de papel na macro escala, podemos entender melhor as formas criadas pela natureza na micro escala. A minha obra de origami na capa, o trabalho intitulado "Inverno num parque de Lisboa", e o capsídeo do vírus Canine parvovirus, um vírus contagioso que ataca sobretudo os cães e outros canídeos, têm a mesma estrutura geométrica do pequeno rombicosidodecaedro, um poliedro com simetria icosaédrica. Essa obra invoca simbolicamente o Ano da Biologia Matemática 2018. 0 origami é uma arte de dobragem do papel, com uma forte componente geométrica, que permite a construção de formas complexas e tem atraído o interesse de matemáticos pelas suas propriedades geométricas e algébricas.

Krystyna Burczyk
Os vírus são responsáveis por inúmeras doenças no homem, nos animais e nas plantas e as curas e prevenções são ainda muitas vezes problemáticas. Desenvolvimentos recentes das aplicações da matemática à virologia, nomeadamente das teorias de grupos, de grafos, de tesselação ou de reticulados, mostraram, por exemplo, que as restrições estruturais às formas dos vírus são maiores do que antes se pensava, e permitiram a construção de novos modelos para o desenvolvimento de terapias anti-virais. Os capsídeos virais que envolvem os genomas dos vírus, por razões de economia genética, tem muitas vezes uma simetria icosaédrica. Ora esta simetria não é cristalográfica em três dimensões, i.e. não é compatível com reticulados periódicos, o que motivou os matemáticos a desenvolverem novas estruturas no contexto de grupos de Coxeter não-cristalográficos que encontraram aplicação não só na virologia, mas também noutras estruturas moleculares da química do carbono.

\section{José Francisco Rodrigues}

Universidade de Lisboa

rce.casadasciencias.org

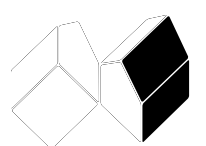




\section{REVISTA DE CIÊNCIA ELEMENTAR}

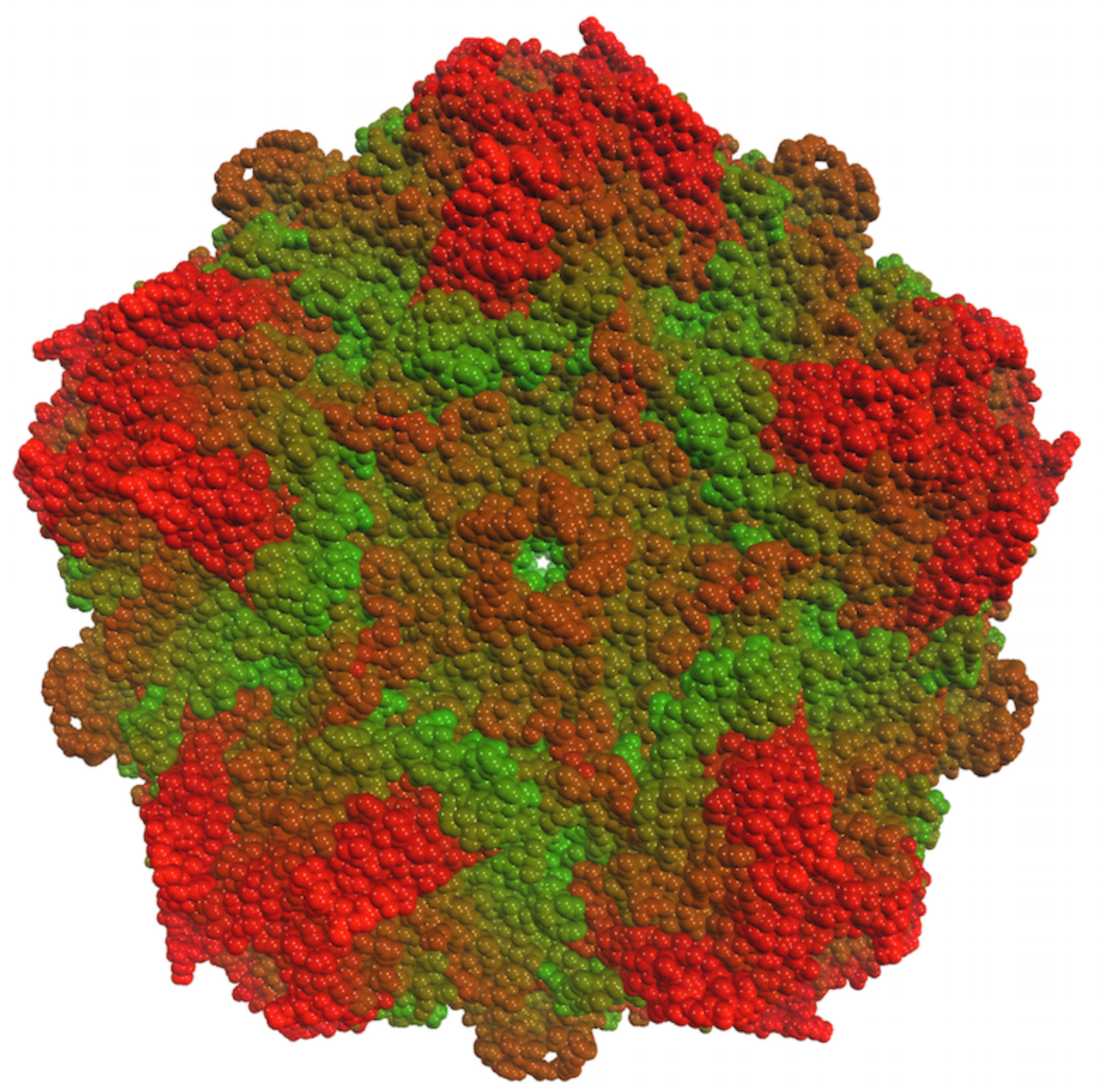

Imagem de Canine Parvovirus, gerada em VMD. Autor: Alexandre Lopes Magalhães. 